\title{
Application of the Technology in Sponge Campus in China
}

\author{
Hu Jiayu*, Xiao Jiewei, Tong Qiaohui, Shu Yang* \\ School of Urban Design, Wuhan University, Wuhan, China \\ Email address: \\ 178120029@qq.com (Hu Jiayu),1017235429@qq.com (Xiao Jiewei), qhtong@whu.edu.cn (Tong Qiaohui), \\ 1318579332@qq.com (Shu Yang) \\ *Corresponding author
}

\section{To cite this article:}

Hu Jiayu, Xiao Jiewei, Shu Yang. Application of the Technology in Sponge Campus in China. International Journal of Architecture, Arts and Applications. Vol. 5, No. 4, 2019, pp. 105-112. doi: 10.11648/j.jjaaa.20190504.13

Received: November 3, 2019; Accepted: December 3, 2019; Published: December 9, 2019

\begin{abstract}
In recent years, China has vigorously promoted the theory of Sponge City to deal with the increasingly serious water problem in urban. As a classification of Sponge City, the theory and practice of Sponge Campus have a huge exemplary effect. In order to facilitate the research, firstly, the paper analyzes the main situation of campus construction in China, points out its shortcomings in the use of rainwater resources, which also reflects the necessity and long-term significance of the Sponge Campus construction in China. In order to further promote the practice and theoretical research of the Sponge Campus in China, this paper analyzes the technology and strategy in the construction and landscape design of several Sponge Campuses at home and abroad, and discusses the planning and design methods of the Sponge Campus. These reference cases not only include the new Sponge Campus projects, but also the sponge transformation of traditional buildings, which has rich reference value. On the basis of cases study and combined with the concrete practices of the Sponge Campus construction, this paper puts forward some design principles of sponge campus construction, expecting the further development of relevant theories, so as to promote the construction of sponge campus for ecological development in China.
\end{abstract}

Keywords: Sponge City, University Campus, Rainwater Infiltration, Landscape Design

\section{Introduction}

After entering the 21 st century, many environmental problems have produced due to the advancement of urbanization. In recent years, with the improvement of people's living standards and the national economy, the problem of ecological environment protection has been paid more and more attention by relevant departments. Because of the rapid urbanization process, the ability of Rainwater infiltration in urban earth's surface is not good, which brings serious waterlogging phenomenon. This situation promotes the corresponding research of urban hydrological cycle and rainwater resource utilization. Among them, the construction and transformation projects of Sponge Campus have developed rapidly in recent years.

Sponge campus refers to the application of sponge city theory and related technologies in a campus environment, building a harmonious campus environment based on ecological protection, and achieving the coordinated development of campus ecological environment and water resources through management and control in source [1].
Sponge city refers to the city has good adaptability in environmental changes and natural disasters, which like a sponge, and realizes the reuse of water resources through the collection, purification, and other technical means on rainwater [2].

Considered to the campus has the characteristics of moderate scale, dense population, large water consumption, and large catchment area, it will bring many benefits if the rainwater there can be utilized reasonably, such as relieving the pressure of water supply, saving water resources and promoting hydrological cycle. Therefore, to a certain extent, the construction of the Sponge Campus can boost the regional ecological balance and hydrological cycle. At the same time, the construction also has an exemplary and promoted effect on the theoretical study of Sponge City.

\section{Current Situation of Campus Construction in China}

Most of our campuses were built in the middle of the last 
century. Due to the limitations of technology and science development during that time, the rainwater treatment facilities are not perfect, and some of them are also aging due to age-old [3]. Generally speaking, there are four aspects of the shortage in the utilization of water resources in Chinese campus; it contains that:

(1) Water sensitivity design. At present, the design method of water sensitivity has not been considered in Chinese campus construction. And the conditions of the hydrological cycle and rainwater concentration in campus have not been considered in the aspects of building layout, road setting, and landscape design. [4]

(2) Paving materials. At present, impervious materials are still mostly used for the pavement of campus roads, squares, and parking ground, which is not conducive to rise the rate of rainwater infiltration. Also, it increased the surface runoff and the pressure of pollution discharge in the pipe network. What's more, waterlogging is very easy to produce during the rainy season. So, the current situation not only affects the campus environment but also causes a waste of rainwater resources.

(3) Landscape design. Campus landscape can be roughly divided into water landscapes and green landscapes. Among them, waterscape is a common means of environmental beautification on campus, but it must be seen that the source of waterscape is most depend on tap water, which has resulted in a serious waste of water resources. The green landscape occupies a large proportion of the composition of the campus landscape, most of which are arranged in large areas. At present, in the campus landscape of our country, the elevation of green space is mostly higher or even equal with the road surface [5]. This situation is not conducive for rainwater storage and can result in a certain degree of soil erosion and ground pollution because the rainwater runoff will also carry some soil.

(4) The age-old pipe network. With the affection of time, some of the aging pipe networks need to be replaced to meet the drainage needs. At the same time, we should also pay attention to the corresponding drainage problems of the pipe network caused by natural reasons, for example, the increase of rainfall due to the change the ecological environment.

These four aspects of the shortage in the campus, have caused serious problems such as waterlogging and ground pollution in the campus during the rainy season. Furthermore, this situation has brought many inconveniences for teachers and students to a large extent. At the same time, it also bad for the campus's environment and the hydrological cycle in the region.

Therefore, the construction of reasonable and effective rainstorm management measures, drainage system, and rainwater resource utilization systems are particularly necessary.

\section{Practices of Sponge Campus Construction in China and Foreign Countries}

In recent years, the research on the theory and technology of Sponge City is in full swing, and the construction practice of Sponge Campus in China has also been developed. In terms of campus planning, academician He Jingtang took the lead in putting forward the new era campus planning theory of "two views and three natures." So, the construction of the Chinese campus has entered a new era of "sponge" [6]. The Sponge Campus construction in foreign countries is more mature than China so that it can be used for reference and learning.

\subsection{Technical Means of Sponge Campus}

Sponge Campus construction is based on the Low Impact Development theory, which also called LID. The LID theory, developed in the 1990s, emphasizes to combine the landscape design method and the construction process of campus. It aims to reduce the adverse impact of rainwater on the environment by source management and control, to reduce the rainwater runoff velocity and pollution and to achieve the ecological balance and hydrological cycle of the area where the protection is located. It also tries to maintain the hydrological characteristics before and after the development is unchanged. Compared with the traditional storm management method, this theory is characterized by three aspects: source management and control, landscape design, and decentralized treatment. At present, LID theory has been used in many foreign cities' development planning and rainwater management regulations.

The technical means of Sponge Campus construction mainly include biological detention pool, green roof, permeable pavement, and sunken green space [7]. Among them, the biological detention pool generally combines landscape design and pollution control, aiming to achieve the purpose of rainwater purification and water regulation by filtration and decomposition of the soil and microorganisms in it. The green roof, also known as roof garden, can effectively slow down rainwater runoff, play a role in water conservation and air purification, and has certain requirements for the structural design strength of the roof in an application. Permeable pavement can slow down runoff and control pollution through permeable pavement materials. Sunken green space, also known as rainwater garden, controls the height of rainwater overflow between the green land elevation and the ground elevation, to promote the reuse of rainwater resources. 


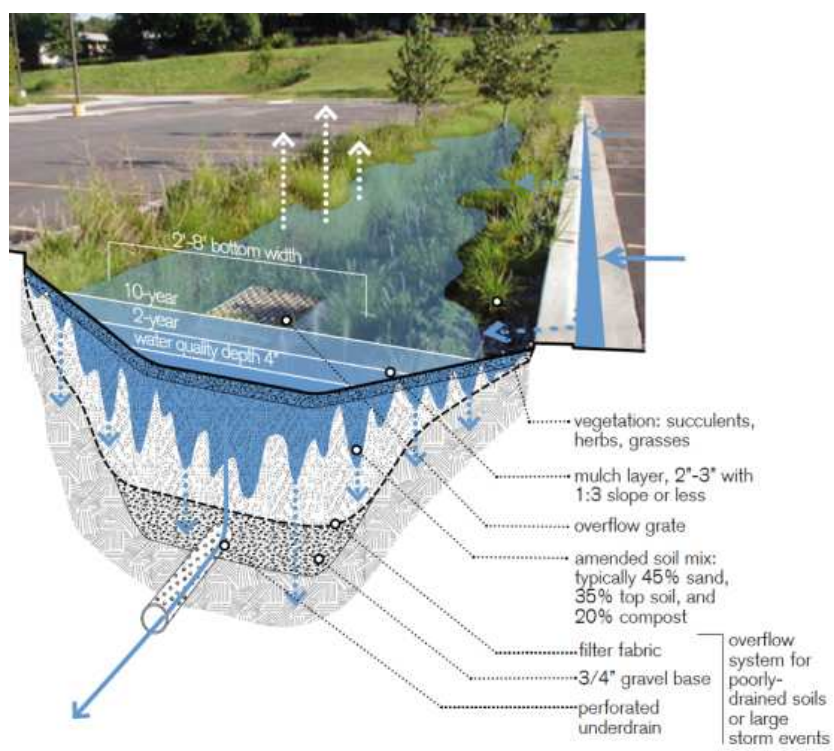

(From: Low Impact Development Manual-2010)

Figure 1. Biological detention pool.

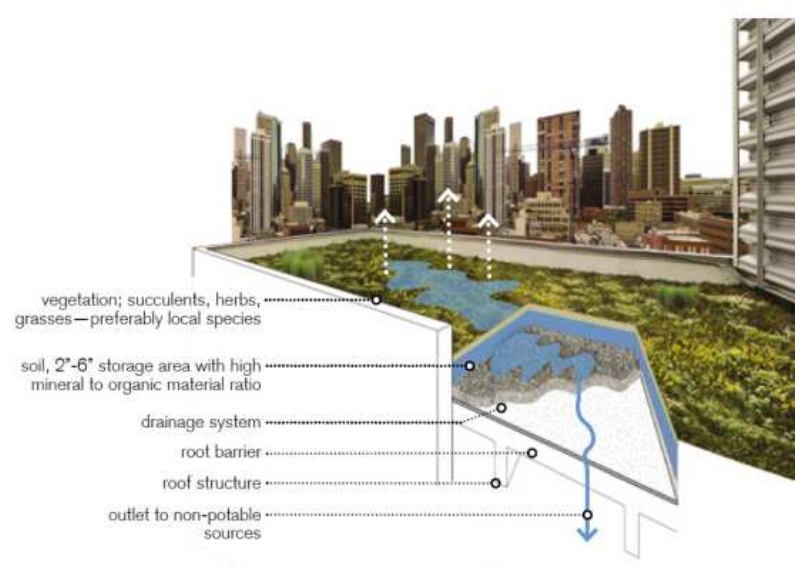

(From: Low Impact Development Manual-2010)

Figure 2. Green roof.

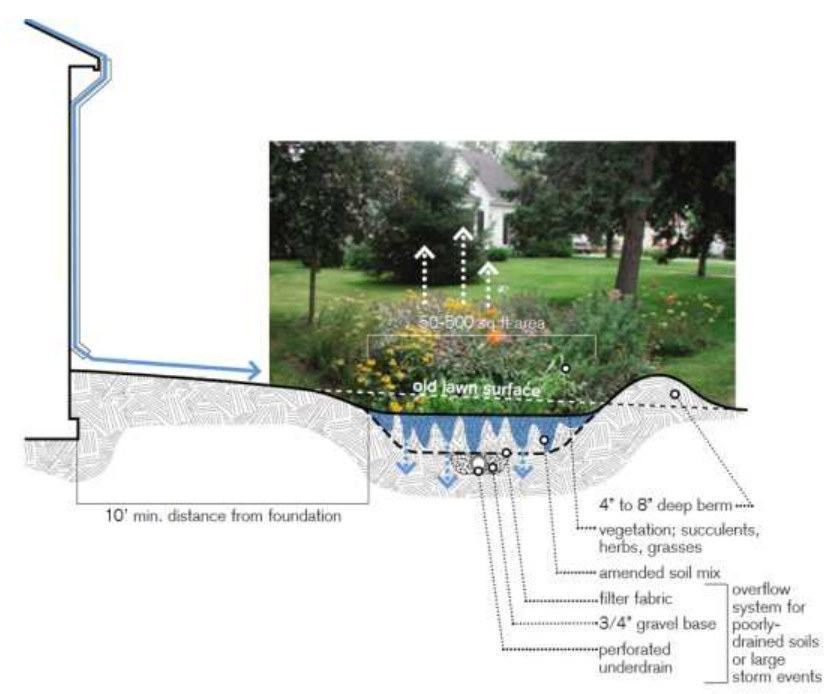

(From: Low Impact Development Manual-2010)

Figure 3. Sunken green space.

\subsection{Practice of Sponge Campus Construction in Foreign Countries}

\subsubsection{Sonoran Landscape Laboratory}

Sonoran landscape laboratory, located at the University of Arizona in Tucson, Arizona, USA, covers an area of 1.2 acres. The project was completed in 2007 and is a low-cost, research- oriented public space, which is also used as an outdoor classroom and entrance plaza. Due to the successful consideration of water collection, climate regulation, air and water purification, water recycling, river wildlife habitat, and other sustainable use strategies in the design, the project had won the 2010 American Association of Landscape Architects Award for comprehensive design [8].

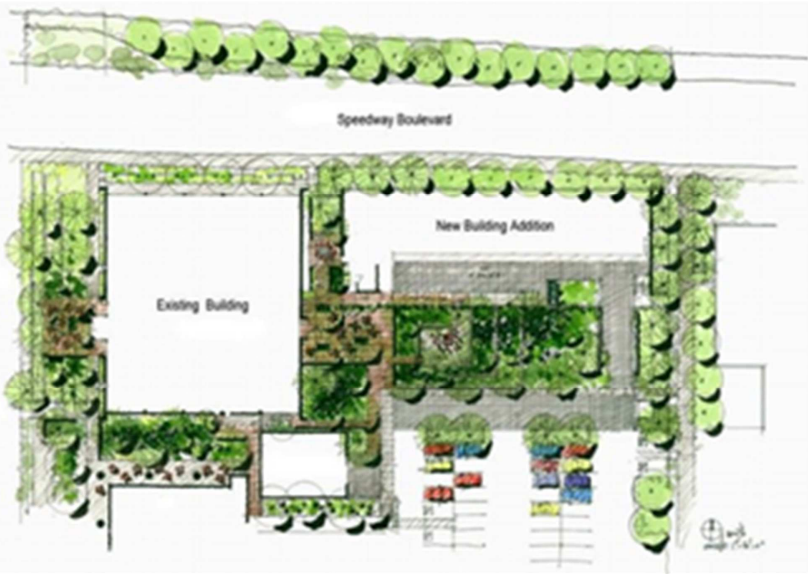

(From: www.landscapeperformance.org)

Figure 4. The general plan of the project

The utilization of water resources is one of the key concerns in the design. In this respect, the project adopts active and passive rainwater collection technologies, such as building water collection, local flood detention, rainwater infiltration and rainwater storage, so as to realize the recycling of rainwater, reduce water consumption and slow down the flow rate of rainwater runoff, and realized the water circulation in the area. Also, the project has also built a water recycling system and an efficient drip irrigation system, including building roof runoff, air conditioning condensate, and domestic wastewater, to realize the full utilization of water resources.

The project mainly uses three technical means of sunken green space, permeable pavement, and biological detention pool to realize the construction planning of Sponge Campus. Among them, the sunken green space, also called rainwater garden, not only creates a good environment microclimate, but also processes the rainwater and the waste water generated in the building through the biological sponge purification method, and store the water at the same time. The permeable pavement, providing outdoor communication space for users, effectively has the function of increasing the probability of rainwater infiltration, slowing down the flow rate of rainwater surface runoff, conserving water and soil, and reducing pollution. As for the biological detention pool, 
it gathers the rainwater and waste water in the water collection tank and plays a role like the "wetland" in the area, which is responsible for water conservation, ecological balance, and hydrological cycle.

Table 1. Application of sponge City Technology.

\begin{tabular}{|c|c|c|}
\hline Engineering measures & Landscape form & Details \\
\hline Sunken Green Space & Rain Garden & $\begin{array}{l}\text { A good microclimate environment is created by a rainwater garden to reduce heat } \\
\text { island effect. }\end{array}$ \\
\hline Permeable Pavement & Bridge, Ramp, Sunken Plaza & $\begin{array}{l}\text { The bridge and ramp are constructed with porous steel plates, and the ground of the } \\
\text { sinking square is paved with permeable materials, which is conducive to rainwater } \\
\text { infiltration. }\end{array}$ \\
\hline Biological Detention Pool & Pond, Desert dry creek & $\begin{array}{l}\text { The collected rainwater will flow into the pond and dry desert stream from the water } \\
\text { collecting tank, slow down the rainwater runoff velocity and increase the rainwater } \\
\text { permeability through a long path. }\end{array}$ \\
\hline
\end{tabular}

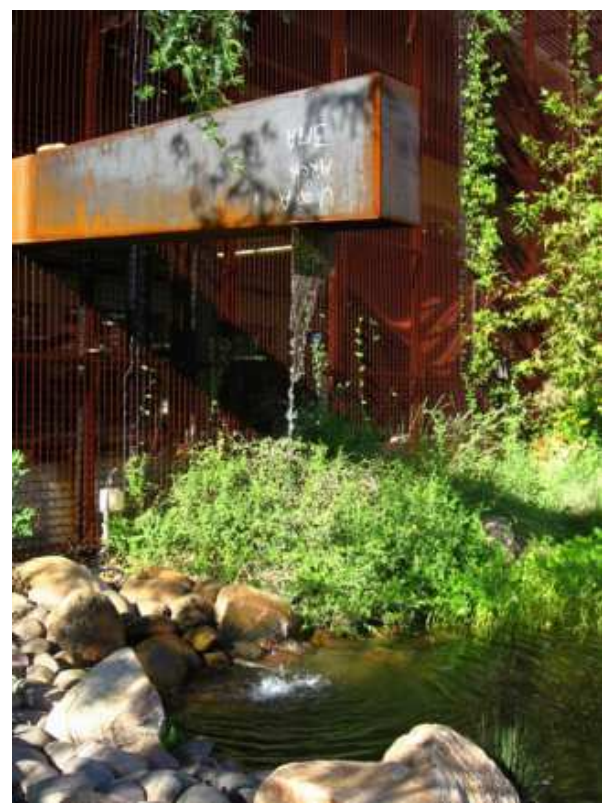

(From: http://wbla-hk.com/content/view?id=330)

Figure 5. Result after transformation.

\subsubsection{Sidwell Friendship Middle School}

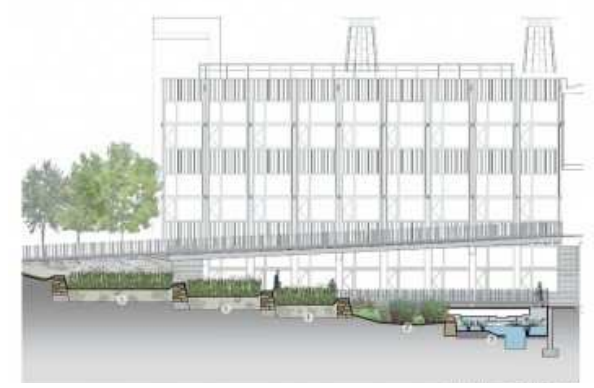

Figure 6. Sectional diagram of multi-layer permeability system.

(From:

https://www.landscapeperformance.org/case-study-briefs/sidwell-friends-mi ddle-school\#/challenge-solution)

Sidwell Friendship Middle School, founded in 1883 in Washington, D.C., is one of the oldest private schools in the United States. It has trained many successful people. The sponge transformation project of the campus has been awarded as one of the top ten green projects of the environmental committee of the American Association of architects in 2007, the special architectural and landscaping technology award of the 2007 Washington architecture conference, the sustainable development award of the American Society of civil architects in 2011 and many other awards in recent years [9].

The sponge technology application of the project is mainly reflected in the sunken green space (rainwater garden) and biological detention pool. The unique point of its construction is that it successfully utilizes the terrain elevation difference in the campus, and combines with the sunken green space technology to design and build a vertical terrace type multi-level infiltration system. The rainwater is filtered through the infiltration system layer by layer and finally reaches the reservoir, to achieve the purpose of purification, and reduction of the surface runoff and maintain the stable hydrological cycle in the region. Also, the system also has good water storage performance. It makes full use of rainwater resources, such as purify rainwater and irrigate plants and reduces the interference of transformation to the minimum of the ecological environment in the area.

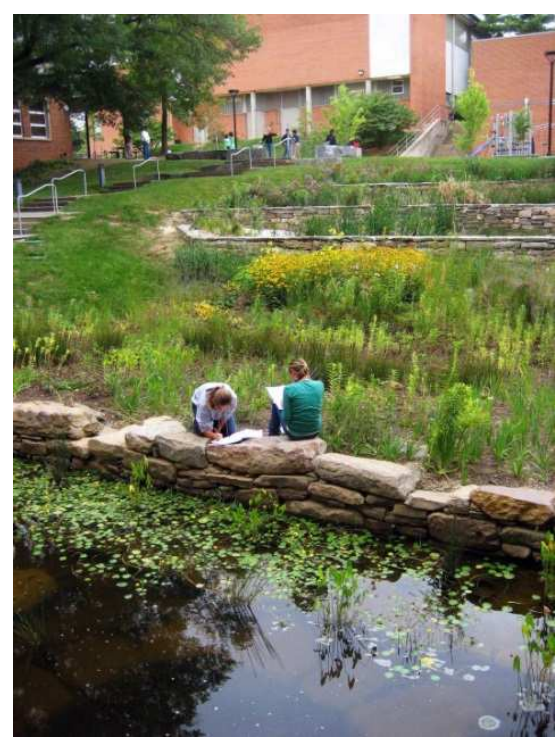

Figure 7. Result after transformation.

(From:

https://www.landscapeperformance.org/case-study-briefs/sidwell-friends-mi ddle-school\#/challenge-solution) 
Table 2. Application of sponge City Technology.

\begin{tabular}{lll}
\hline Engineering measures & Landscape form & Details \\
\hline Sunken Green Space & Rain Garden & $\begin{array}{l}\text { A good microclimate environment is created by the rainwater garden to } \\
\text { reduce heat island effect. } \\
\text { To reduce the surface runoff, maintain the stable hydrological cycle in the } \\
\text { region, and make full use of rainwater resources, for example, purify } \\
\text { rainwater. }\end{array}$ \\
\hline
\end{tabular}

Since it was built in 2007, after years of calculation, the system can prevent more than 317,900 gallons of waste water from entering the sewage system of the District of Columbia every year, saving \$1,687 in sewage cost [3].

\subsection{Practice of Sponge Campus Construction in China}

\subsubsection{Civil Structure Experimental Building of Shenzhen University}

The Civil Structure Experiment Building of Shenzhen University covers an area of about 1.3 hectares, including the structure experiment hall on the west side, the buildings on the north side, the middle side and the south side, and 907 square meters of landscape courtyard. The total floor area of the building is about 4025 square meters [10].

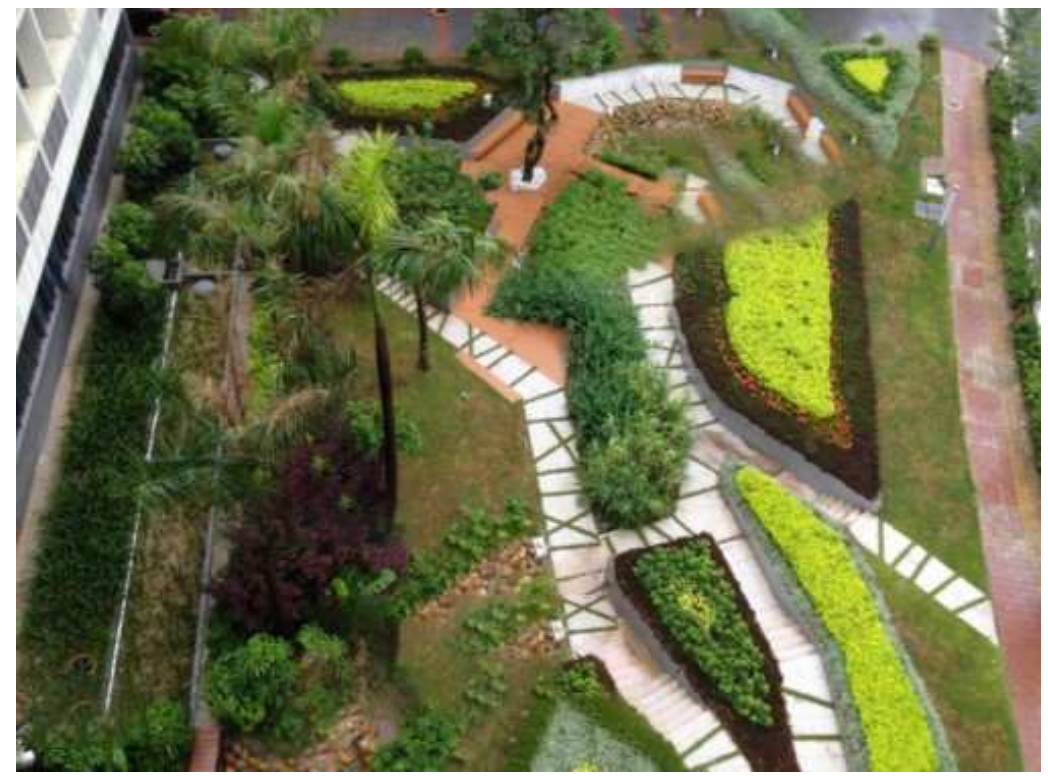

(From: The application of low impact development (LID) technology in the structural experiment building of Shenzhen University)

Figure 8. Technical layout.

The sponge construction technology of the project is mainly reflected in three aspects: green roof, permeable pavement, and biological detention pool. Among them, the biological detention pool is equivalent to the wetland in this area, which is responsible for water storage and conservation, water and soil conservation, and air purification. Also, the project also used four different working media to treat rainwater in different degrees and monitored rainwater runoff and quality. Pervious pavement is reflected in the pavement of the sidewalk. The use of a large number of pervious bricks greatly reduces the rainwater runoff, raise the rainwater permeability, and effectively maintains a good hydrological cycle in the area.

Above all, the project is a rainwater treatment and reuse facility integrating the functions of circulating water system, climate, and hydrological data monitoring and collection.

Except for using the above-mentioned technical means to maintain the regional ecological balance, the project also designs the lighting, leisure, and landscape beautification projects in the roof and courtyard, which have created a leisure space with rich landscape.

Table 3. Application of sponge City Technology.

\begin{tabular}{lll}
\hline Engineering measures & Landscape form & Details \\
\hline Green Roof & Roof greening & $\begin{array}{l}\text { Create a good microclimate environment and reduce the heat island effect. } \\
\text { Water permeable brick is made of waste construction waste, which is conducive } \\
\text { Permeable Pavement }\end{array}$ \\
$\begin{array}{ll}\text { Sidewalk } \\
\text { to rainwater infiltration. } \\
\text { It plays the role of water storage, water conservation, and air purification and } \\
\text { effectively slows down the flow rate of rainwater runoff and increases rainwater } \\
\text { permeability. }\end{array}$ \\
\hline
\end{tabular}




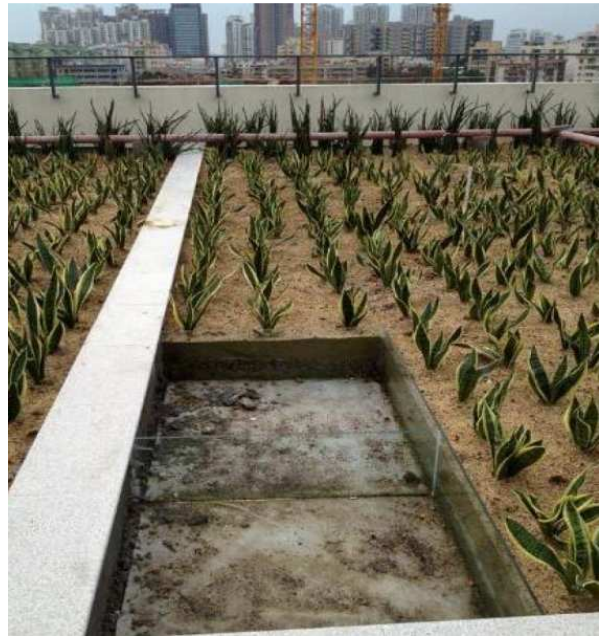

Figure 9. Green roof schematic.

(From: The application of low impact development (LID) technology in the structural experiment building of Shenzhen University)

\subsubsection{Tsinghua University Shengyinyuan}

Tsinghua University Shengyinyuan is one of the modern teachers' residential architectural complex of Tsinghua University campus. It was built in about 1946 by Jitai Engineering Department. What's more, it is also the last work of the Jitai Engineering Department on the campus of Tsinghua University. In recent years, Tsinghua University has carried out a protective restoration of this architectural complex [11].

Since the building was built, with the continuous construction of Tsinghua University campus, the terrain around the ground has been continuously improved, and it has gradually become a low-lying area in the campus [12]. Every rainy season, serious waterlogging occurs in Shengyinyuan, which brings many disadvantages to the protection of buildings and the life of people around.

This sponge transformation project is based on the special historical background and place of Shengyin University and paid attention to these three aspects, namely, the school history education place and memorial space, the humanities research office area with Tsinghua characteristics and the "Green University" rainwater management demonstration place [13]. Therefore, the project is a "sponge" plan combining history, landscape, and transformation.

The technical means used in the project mainly include sunken green space (rainwater garden) and permeable pavement. Also, the rainwater garden has been settled six on the campus, and the overflow outlets are respectively set according to different terrain height. These rainwater gardens are connected by shallow grass and gravel to form a linkage regulation mechanism for rainwater, to effectively avoid waterlogging caused by abundant rainfall. The application of permeable pavement laying between the single buildings can increase rainwater infiltration through the use of permeable materials, and reduce the pollution and soil erosion caused by ground runoff. Also, the gabion device used in the rainwater garden not only has a good landscape effect but also has a good filtering effect on the rainwater. With the increase of soil impurities in the gap of gabion, it is possible for the natural growth of plants.

Table 4. Application of sponge City Technology.

\begin{tabular}{lll}
\hline Engineering measures & Landscape form & Details \\
\hline Sunken Green Space & Rain Garden & $\begin{array}{l}\text { Create a good microclimate environment, reduce the heat island effect, } \\
\text { water storage, water conservation, air purification, and effectively slow } \\
\text { down the flow rate of rainwater runoff, increase rainwater permeability. } \\
\text { Permeable Pavement }\end{array}$ \\
Sidewalk & $\begin{array}{l}\text { Water permeable brick is made of waste construction waste, which is } \\
\text { conducive to rainwater infiltration. }\end{array}$ \\
\hline
\end{tabular}

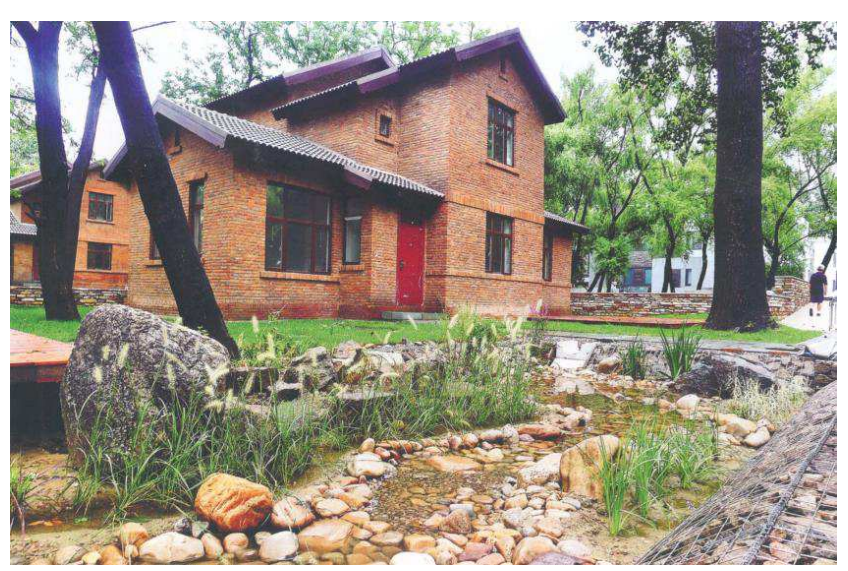

(From: Landscape of Shengyin College of Tsinghua University)

Figure 10. Green roof schematic.

\subsubsection{Water Environment Design of Kunshan Duke University}

The water environment design project of Kunshan Duke University belongs to the construction project of the first part of the campus, which includes five buildings around the central water area, which called academic center, conference center, innovation center, and dormitory for teachers and students.

Based on the unique site conditions of the project, in the planning process of Sponge Campus, the height change of water surface level in four seasons in the campus is taken as the focus of the design, to form an "elastic" ecosystem. Because Kunshan is located in the lower reaches of the Yangtze River, the water level in there often changes with the rainy season' coming. Therefore, in this design, the area of the outdoor square and hydrophilic platform in the dry season will be reduced in layers in the rainy season and normal season. The water ecosystem formed from this shows the 
dynamic characteristics of seasonal change [14].

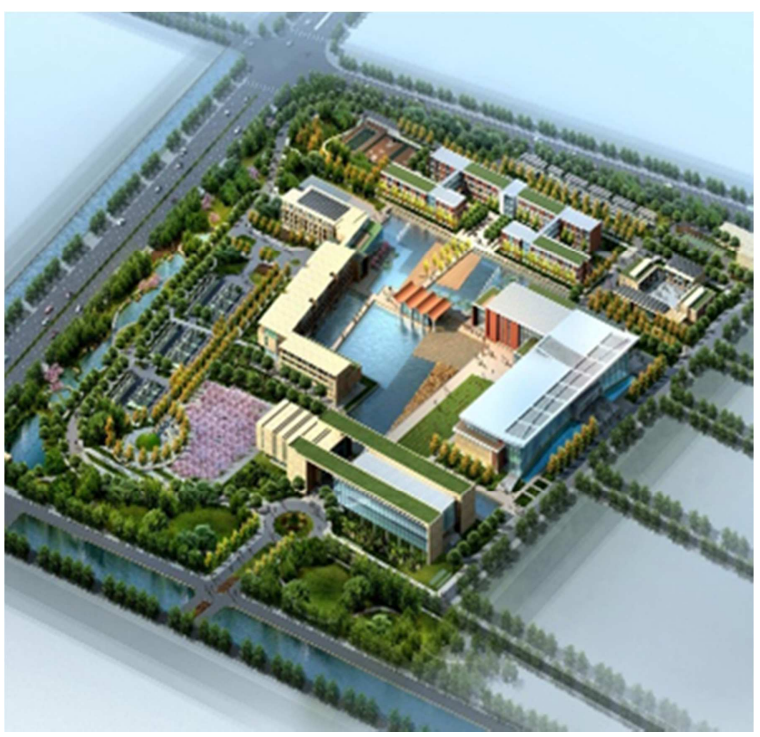

Figure 11. The campus of Kunshan Duke University.

(From: "Good as water" -- ecological landscape design of Kunshan Duke University)

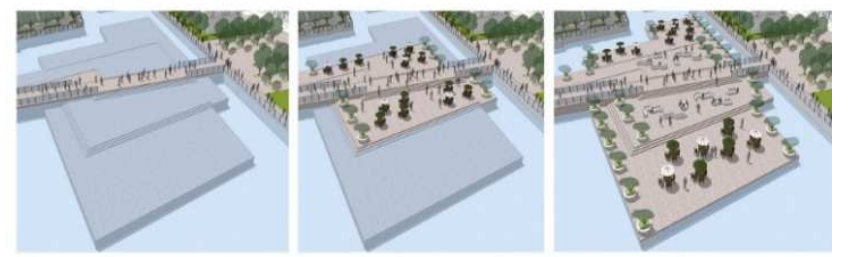

Figure 12. Conceptual map of spatial water level change (rainy season, normal season and dry season from left to right).

(From: "Good as water" -- ecological landscape design of Kunshan Duke University)

Sponge city technology is mainly reflected in the application of sunken green space, which performance is a rainwater garden in this project. The water ecosystem with the variable water level in four seasons can play a good role in rainwater storage and reduce excessive surface runoff, to effectively maintain water and soil balance and stable hydrological cycle in the campus area. Except for completing landscape design and beautifying the campus environment, the functional system of rainwater collection, treatment, and reuse has been successfully established to solve the problem of water supply pressure and waterlogging in the campus [6]. Also, the water ecological network in the central area of the campus also acts an important role in regulating regional air quality and forming a good microclimate environment.

Table 5. Application of sponge City Technology.

\begin{tabular}{lll}
\hline $\begin{array}{l}\text { Engineering } \\
\text { measures }\end{array}$ & $\begin{array}{l}\text { Landscape } \\
\text { form }\end{array}$ & Details \\
\hline $\begin{array}{l}\text { Sunken Green } \\
\text { Space }\end{array}$ & $\begin{array}{l}\text { Rain } \\
\text { Garden }\end{array}$ & $\begin{array}{l}\text { Benefit for rainwater storage, reduction } \\
\text { of excessive surface runoff, maintain } \\
\text { water and soil balance and stable } \\
\text { hydrological cycle in the campus area }\end{array}$ \\
\hline
\end{tabular}

\section{Principles of Sponge Campus Construction}

\subsection{Ecological Cycle}

Based on protecting the original ecological environment of the campus and taking the Low Impact Development as the theoretical basis, the Sponge Campus is constructed by using the original facilities preferentially to realize the recycling of rainwater resources in the area and further promote the ecological balance.

\subsection{Adapt to Local Conditions}

Adjusting measures to local conditions is not only the prerequisite and necessary condition of ecological environment protection but also the essence of sponge campus. In the construction or reconstruction of Sponge Campus, the natural geographical conditions and surrounding environmental conditions of the construction base shall be fully considered, and the appropriate technical means shall be selected under the guidance of the theory affecting the development, to achieve the expected effect.

\subsection{Overall Coordination}

The overall coordination includes not only the coordination consideration of the old and new parts in the reconstruction and construction projects but also the careful consideration of landscape effect, building safety performance, ecological effect, and many other aspects. How to make the site better in the transformation and further develop the existing advantages of the site is closely related to the overall coordination.

\section{Conclusion}

The corresponding theory and technology research of Sponge City plays a very important role in boosting the practice of Sponge Campus. According to the different environmental conditions and functions of the campus itself, Sponge City technology has been applied to different degrees in campus planning.

At present, Chinese Sponge Campus planning is still in a vigorous development stage. Compared with the practice of foreign Sponge Campus, there are some deficiencies. In addition to a small number of new projects, transformation practice still needs to be developed. It also should be noted that Sponge Campus practice in China lacks corresponding post- use evaluation, which is an important feedback link in the practice process [15]. To some extent, this phenomenon hinders further development and research of Sponge Campus design and theory. In the future campus planning, we should pay enough attention to post-use evaluation to promote the further development of Sponge Campus. 


\section{Acknowledgements}

This paper is one of the phased studies of the Youth Fund of NSFC Project (China, 51508422) and the general course project of Wuhan University (China, 413200041), which name is Research on water sensitive space design method based on elastic City Theory -- Taking Wuhan as an example.

\section{References}

[1] Hao Yu, Cao Lei, Li Yu. Low impact development design in green campus landscape. Building Technology. 2014 (9), pp. 114-117.

[2] Liu Deming etc. Introduction to sponge City Construction -- let the city breathe like a sponge. [M]. Beijing: China Construction Industry Press, 2017, pp. 48-49. [2]

[3] Pan Chuliang. A Review of the Practice on Sponge Campus.

[4] Michael E. Dietz. Low Impact Development Practices: A Review of Current Research and Recommendations for Future Directions [J]. Water Air Soil Pollut, 2007, 186, pp. 351-363.

[5] Li Rui. Application of Rainwater Infiltration Facility Based on Low Impact Development in Campus Landscape and Guidance to Wuhan University Campus Landscape.

[6] He Jingtang. The theory and practice of contemporary university campus planning. Beijing: China Construction Industry Press, 2010.

[7] Hu Yin. Study on the low impact development and optimization design scheme based on sponge campus construction. Water Saving Irrigation, 2016 (12), pp. 112-115.
[8] Li Mufei. Sonoran Landscape Laboratory [J]. Landscape Design, 2010 (5), pp. 12-17.

[9] [Sidwell Friends https://www.landscapeperformance.org/case-study-briefs/sidw ell-friends-middle-school [EB/OL].

[10] Li Zhuoxin, Chen Shicong. The application of low impact development (LID) technology in the structural experiment building of Shenzhen University. Construction engineering technology and design, 2014 (16).

[11] Wang Qiang, Liu Shihong, Yu Dingwen. The protective renewal of modern architecture in Shengyin college, Tsinghua University, Beijing. Thesis collection of the 13th academic annual meeting of modern Chinese architecture history, Tsinghua University, China Architecture Society. 2012: 517-524.

[12] Department of landscape science, School of architecture, Tsinghua University. Landscape of Shengyin College of Tsinghua University. Beijing: World Architecture, 2014 (2), pp. 68-73.

[13] Liu Hailong, Zhang Danming, Li Jinchen, Jie Henan. The integration of landscape hydrology and historical sites. Chinese Gardens, 2014 (1), pp. 7-12.

[14] Shi Huilai, Lin Zhongjie. "Good as water" -- ecological landscape design of Kunshan Duke University. Architectural Journal. 2018, (3), pp. 94-100.

[15] Li Xiang. Research on the utilization status and satisfaction evaluation of lid measures in Chengdu University. Chengdu: Sichuan Agricultural University, 2016, pp. 59-69. 